\title{
Reparative T lymphocytes in organ injury
}

\author{
Franco R. D'Alessio, ${ }^{1}$ Johanna T. Kurzhagen, ${ }^{2}$ and Hamid Rabb ${ }^{2}$ \\ 'Division of Pulmonary and Critical Care Medicine and 'Division of Nephrology, Johns Hopkins University School of Medicine, Baltimore, Maryland, USA.
}

\begin{abstract}
Acute organ injuries such as acute cerebrovascular accidents, myocardial infarction, acute kidney injury, acute lung injury, and others are among the leading causes of death worldwide. Dysregulated or insufficient organ repair mechanisms limit restoration of homeostasis and contribute to chronic organ failure. Studies reveal that both humans and mice harness potent non-stem cells that are capable of directly or indirectly promoting tissue repair. Specific populations of T lymphocytes have emerged as important reparative cells with context-specific actions. These $T$ cells can resolve inflammation and secrete reparative cytokines and growth factors as well as interact with other immune and stromal cells to promote the complex and active process of tissue repair. This Review focuses on the major populations of $T$ lymphocytes known to mediate tissue repair, their reparative mechanisms, and the diseases in which they have been implicated. Elucidating and harnessing the mechanisms that promote the reparative functions of these T cells could greatly improve organ dysfunction after acute injury.
\end{abstract}

\section{Introduction}

Acute, repeated, and chronic injuries lead to organ dysfunction. In the aftermath of injury, tissue repair and regeneration are essential to restoring organ homeostasis, and defective or insufficient repair mechanisms can lead to permanent organ dysfunction. Tissue repair is an active, complex, and highly regulated process, and tissue response to injury involves a well-studied inflammatory response characterized by influx of immune cells and their activation. However, much less is known about the role of inflammation and the immune system in repair. The importance of inflammation in repair is highlighted by observations that glucocorticoid use, which inhibits immune responses, also impairs repair (1). Moreover, a timely resolution of inflammation is required for repair (2).

$\mathrm{T}$ lymphocytes are pivotal for the maintenance of adaptive immune responses, including recognition of pathogens, allergens, and tumor antigens. Moreover, although T lymphocytes coordinate and maintain immunological memory and self-tolerance, they have also been linked to inflammatory and autoimmune diseases (3). For instance, type 2 immune cells involved in allergic inflammation or parasitic infection can also regulate tissue repair $(4,5)$. Interplay between immune cells (macrophages, type 2 innate lymphoid cells, T cells, etc.) and nonimmune cells (fibroblasts, epithelial cells, endothelial cells, stem cells, etc.) helps to direct their responses to environmental cues, as well as epigenetic and metabolic reprogramming during tissue repair. This Review will focus on the major populations of reparative $\mathrm{T}$ cells, describe their role in specific contexts, and present approaches to harness them to enhance tissue repair (Figures 1 and 2).

Authorship note: FRD and JTK contributed equally to this work. Conflict of interest: The authors have declared that no conflict of interest exists. Copyright: (5) 2019, American Society for Clinical Investigation. Reference information: / Clin Invest. 2019;129(7):2608-2618. https://doi.org/10.1172/JCI124614.

\section{$\mathrm{CD4}^{+} \mathrm{Foxp3}^{+}$Tregs}

Regulatory $\mathrm{T}$ cells (Tregs) have emerged as critical orchestrators of resolution of inflammation. These $\mathrm{T}$ cells can mediate repair by dampening inflammation, by modulating other important repair cells such as macrophages, and by synthesizing pro-repair molecules such as amphiregulin (AREG) or keratinocyte growth factor $(\mathrm{KGF})$ that directly promote tissue regeneration. In humans and in mice, Tregs constitute $5 \%$ to $10 \%$ of the total $\mathrm{CD}^{+}$pool, or $1 \%$ to $2 \%$ of peripheral blood lymphocytes. Despite their relatively low frequency, Tregs are among the master regulators of the immune system, with established roles in immune tolerance, homeostasis, and inflammation $(6,7)$. Treg relevance is highlighted by descriptions of humans who carry mutations in the master transcription factor forkhead box P3 (FOXP3) and exhibit massive multisystem inflammation and autoimmunity (immunodysregulation polyendocrinopathy enteropathy X-linked syndrome, or IPEX syndrome) (8-10). A murine counterpart with severe, generalized autoimmunity has been described in scurfy mice (11).

Foxp3 is currently the best available marker to identify Tregs, although it can also be transiently expressed in human activated conventional $\mathrm{T}$ cells (12). A combination of $\mathrm{CD}^{+} \mathrm{CD} 4^{+} \mathrm{CD} 127^{\text {lo }}$ $\mathrm{CD} 25^{\text {hiFoxp }} 3^{+}$is often used to discriminate human Tregs from activated conventional $\mathrm{T}$ cells (13). Natural or thymus-derived Tregs (tTregs) can be distinguished from induced/adaptive or peripherally derived Tregs (pTregs). pTregs can be induced from $\mathrm{CD}^{+}$conventional $\mathrm{T}$ cells by antigenic $\mathrm{T}$ cell receptor (TCR) stimulation with low-dose/high-affinity ligands, suboptimal costimulation, and mediators including TGF- $\beta 1$, IL-2, and retinoic acid (14-16). Helios and neuropilin-1 are enriched in tTregs compared with pTregs $(17,18)$, but caution should be used to discriminate the Treg population when inflammation or overt $\mathrm{T}$ cell activation is present. Another difference is that CpG motifs in conserved noncoding DNA sequence 2 (CNS2), a Treg-specific demethylated region, are demethylated in tTregs, but not in pTregs (19). In contrast, CNS1 at the Foxp3 locus has an important role in pTreg generation, while CNS3 has potent effects in increasing Treg frequency in the thymus and the periphery (16). 


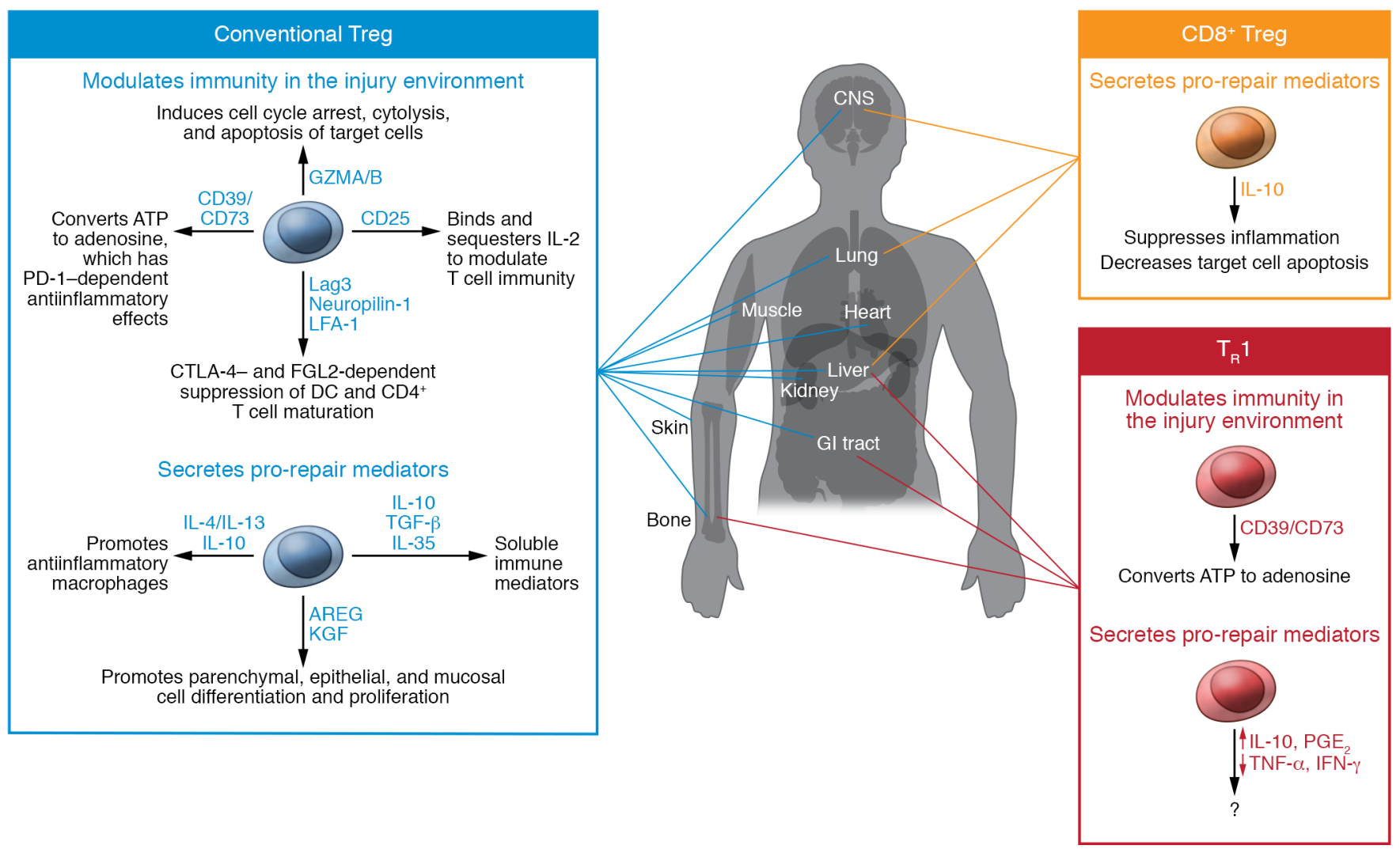

Figure 1. Roles for Treg subsets in repair. Conventional Tregs, $C D 8^{+}$Tregs, and $T_{R} 1$ cells can directly influence repair processes by secreting pro-repair mediators. Conventional Tregs and $\mathrm{T}_{R} 1$ cells also regulate other immune processes at the site of injury.

The importance of Tregs in self-tolerance and maintenance of immune homeostasis has been well established, with an emerging literature demonstrating that Tregs harness potent pro-repair functions in a wide range of immune and nonimmune diseases (Table 1). Tregs can exert their pro-repair function in different organs and diverse contexts (Tables 2 and 3). Treg pro-repair mechanisms can include one or more of the following (Figure 1):

Contact-dependent modulation of effector cells. Tregs can dampen immune responses and thus limit overt inflammation to promote a reparative milieu. Among the contact-dependent mechanisms, expression of high levels of inhibitory receptors (e.g., CTLA-4, LAG-3) can downregulate costimulatory molecules on dendritic cells (DCs) (20-22). Tregs can also downregulate the costimulatory molecules CD80 and CD86 in DCs and promote DC production of indoleamine 2,3-dioxygenase, a potent immunosuppressive enzyme, which in turn results in suppression of effector $\mathrm{T}$ cells $(23,24)$. Treg-driven metabolic disruption involves both apoptosis mediated by CD25-dependent cytokine deprivation (25) and immunosuppression mediated by CD39/CD73-generated cAMP via the adenosine-purinergic adenosine $A_{2 A}$ receptor (26, 27). While granzyme-induced cytolysis is a key mechanism for NK cells and cytotoxic $\mathrm{CD} 8^{+} \mathrm{T}$ cells, Tregs can also express granzymes, which have been shown to be important in controlling respiratory syncytial virus-induced lung inflammation (28), in preventing gastrointestinal graft-versus-host disease (GvHD) (29), and as a mechanism underlying self-induced apoptosis after activation (30).
Secretion of immunosuppressive molecules. Tregs can produce the antiinflammatory molecules IL-10, TGF- $\beta 1$, and IL- 35 , with highly variable mechanisms that can be context-specific. In asthma models, Treg-induced IL-10 production by $\mathrm{CD} 4^{+}$effector T cells suppressed allergic inflammation, although the mechanism did not require IL-10 expression in Tregs themselves (31). In other studies, Treg-derived IL-10 was shown to control lung allergic inflammation (32). In contrast, Treg-derived IL-10 was not necessary to resolve lung injury caused by intratracheal lipopolysaccharide (33). Models of renal ischemia/reperfusion and colitis show important roles for production of IL-10 by Tregs $(34,35)$. The importance of TGF- $\beta 1$ production by Tregs is controversial; however, membrane-tethered TGF- $\beta$ has been shown to be immunosuppressive in both allergic and autoimmune diseases $(36,37)$. IL-35 has been shown to have robust Treg suppressive function in vitro and in vivo and can generate a suppressive population of pTregs (38).

Secretion of pro-repair mediators. Treg-derived AREG, an EGFR ligand, has been shown to exert potent reparative function in models of muscle injury (39), influenza-induced lung injury (40), and colitis (41). Several mediators can induce AREG, including IL-33, cAMP, insulin-like growth factor-1 (IGF-1), TGF- $\beta$, and prostaglan$\operatorname{din} E_{2}(42,43)$, each of which contributes to rapid upregulation of AREG during inflammation/injury. In contrast to other EGFR ligands, AREG can induce both mitogenic and cell differentiation signals, placing AREG at center stage in coordination of tissue homeostasis and epithelial repair after injury (43). KGF secreted 


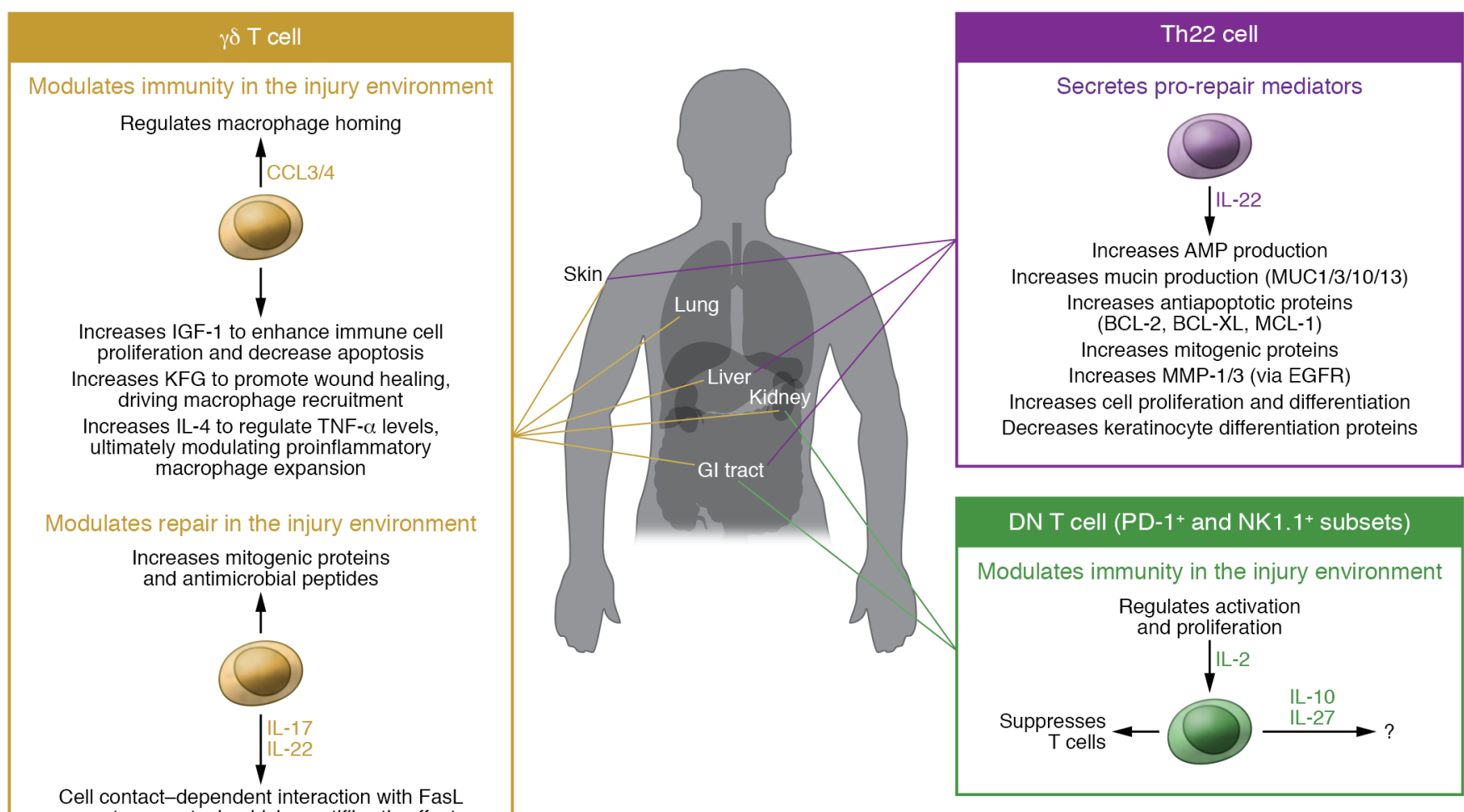

Figure 2. Roles for other T cell subsets in repair. $\gamma \delta$ T cells, Th22 cells, and DN T cells influence immunity and repair at the site of injury via a variety of mechanisms.

by activated Tregs has also been shown to be an important factor in promoting alveolar epithelial repair after lung injury (44). Tregs can also promote angiogenesis $(45,46)$, possibly through enhancement of VEGF production by other cells, as Treg production of angiogenic factors has not been described to date. An additional factor secreted by Tregs is IL-4, which can induce alternative activation and promote a reparative phenotype in human macrophages (47).

Modulation of stromal cells. Tregs can modulate stromal cells to promote repair. Stromal/Treg signaling via the IL-33/ST2 axis has been reported to expand Tregs in injured lungs, muscle, colon, and liver (48-50). Tissue injury leads to release of alarmins, among them IL-33, which can stimulate Tregs through their receptor, stimulation-2 (ST2). IL-33-stimulated Tregs upregulated reparative AREG production by $\mathrm{ST}_{2}{ }^{+}$Tregs, contributing to the reprogramming of infiltrating macrophages to a pro-repair phenotype $(51,52)$. IL-33/ST2 signaling can mediate tissue-reparative functions in the resolution phase after injury in different organ systems, although it may play pathological roles in type 2 diseases such as skin and lung allergic pathologies (53-55). Moreover, Treg contact-dependent and -independent cellular interactions with epithelial, endothelial, fibroblast, or other stromal cells can mediate their reparative effector functions. The complexity of Tregs orchestrating repair is highlighted by the migration of these cells to inflamed lungs, where they modulate alveolar macrophage proinflammatory responses, enhance neutrophil clearance by macrophage efferocytosis, and balance effector Th1/Th17 responses while promoting epithelial and endothelial proliferation $(33,40,56,57)$.
Modulation of stem cells. Tregs' pro-repair functions suggest that they may influence tissue-specific stem cell functions. In a model of epithelial regeneration, Tregs were shown to promote hair follicle stem cell differentiation (58). Future work will be needed to determine how Tregs interact with niche-specific stem cells in organ repair.

Intense efforts have been made to use Tregs as immunotherapy for autoimmune diseases and solid organ transplantation, with ongoing trials for type 1 diabetes mellitus (NCT02691247; ClinicalTrials.gov) and GvHD (NCT01937468). Although phase I trials using polyclonal Tregs have demonstrated safety to date, there are unique challenges to developing these therapies, including improving the isolation, expansion, purity, stability, potency, and specificity of Tregs (59). It is anticipated that indications for Treg immunotherapy will expand to include other conditions in which unremitting inflammation or persistent organ damage exists. It has been proposed that chimeric antigen receptors (CARs) or antigen-specific Treg TCRs engineered for a specific organ or disease could be developed as the next generation of cell immunotherapy (60).

Adoptive transfer of expanded Tregs requires time, making them an impractical option during the acute phase of organ injury. Repurposing approved drugs to expand and promote endogenous Tregs represents an alternative option. IL-2/anti-IL-2 complex, IL-33 agonists, mTOR inhibitors (e.g., rapamycin), and DNA methyltransferase inhibitors (e.g., decitabine, azacitidine, etc.) can promote Treg expansion, resolve inflammation, and enhance organ repair $(61,62)$. In addition, autologous Treg 
Table 1. T cell types involved in tissue repair and their markers and functions

\begin{tabular}{ll}
$\begin{array}{l}\text { Treg populations } \\
\text { Conventional Tregs }\end{array}$ & Markers \\
\hline tTregs and pTregs & $\begin{array}{l}C D 4^{+} C D 25^{+} F_{0 x p} 3^{+} \rightarrow C D 3^{+} C D 4^{+} C D 127^{\circ}{ }^{\circ} D 25^{\text {hiFoxp }} 3^{+} \\
\text {discriminates human Tregs from activated conventional } \\
\text { T cells (13) }\end{array}$
\end{tabular}

Other Treg subtypes (selection) CD8 ${ }^{+}$Tregs

Foxp3- Tregs

$\mathrm{CD} 8^{+} \mathrm{CD} 28^{-110 /+}$

CD8 $8^{+} \mathrm{CD} 122^{+}$(mouse) $/ \mathrm{CD} 8^{+} \mathrm{CXCD3^{+ }}$ (human)

Qa-1-restricted CD8 ${ }^{+}$(mouse)/HLA-E (human)

$\mathrm{T}_{\mathrm{R}} 1 \rightarrow \mathrm{CD}^{+} \mathrm{CD}^{-} \mathrm{b}^{+} \mathrm{LAG}-3^{+}(65)$
Functions

Repair (see Tables 2 and 3)

Control (suppress) immune responses including self-antigen tolerance and prevent autoimmune disease $(122,123)$

Regulation of immune responses (124) in: tumor immunity (125), allergy (126), transplant rejection (127), infections (128)

Repair (see Tables 2 and 3)

Maintain immune homeostasis/tolerance and inhibit autoimmune disease $(129,130)$

In cancer: inhibit immune responses (116)

Repair (see Tables 2 and 3)

Induce and maintain antigen tolerance

Control (suppress) immune responses: CvHD (131), autoimmunity (73), tissue inflammation (73), transplantation (77)

Other reparative T lymphocyte populations

$\begin{array}{ll}\text { IL-22 }{ }^{+} \text {CD4 } 4^{+} \text {T cells (Th22 cells) } & \text { IL-22 } \\ & \begin{array}{l}\text { Differentiated from Th cells by absence of IFN- } \gamma, \\ \text { IL-5, and IL-17 }\end{array} \\ \text { Double-negative (DN) T cells } \quad \begin{array}{l}\text { CD4-CD8- }, \alpha \beta \text { TCR }^{+} \\ \text {There is no specific marker for DN T cells. Other DN } \\ \text { populations are also described, e.g., DN } \gamma \delta \text { T cells, } \\ \text { DN NKT cells, DN Tregs }\end{array}\end{array}$

$\begin{array}{ll}\gamma \delta \text { T cells } & \text { TCR consists of } \gamma \text { chain and } \delta \text { chain } \\ & \text { Different oligoclonal or monoclonal populations }\end{array}$

Repair (see Tables 2 and 3)

Protect against infections (with exceptions) $(80,132)$

Role in cancer initiation and progression (with exceptions) $(85,92)$

Protective and pathogenic role in autoimmune disease (133)

Repair (see Tables 2 and 3)

Immune regulation and tolerance: graft tolerance (96), antitumoral potential (98), autoimmunity (97)

Exceptions: IL-17-producing DN T cells in SLE (99), IL-17- and IL-23-producing DN T cells in bacterial infection (134)

Tissue homeostasis and repair (ref. 108 and see Tables 2 and 3 )

Located in surface epithelia/mucosa (104)

Cancer immune response (pro- and antitumor effects) (135)

Infection defense (136)

SLE, systemic lupus erythematosus.

function could be enhanced ex vivo for a shorter duration in the presence of these "Treg enhancers" and adoptively transferred back to the host to achieve their pro-repair functions (63).

\section{Type 1 regulatory T cells}

Type 1 regulatory $\mathrm{T}$ cells $\left(\mathrm{T}_{\mathrm{R}} 1\right)$ are a $\mathrm{CD} 4^{+}$population that was initially found to suppress antigen-specific responses to prevent colitis (64). $\mathrm{T}_{\mathrm{R}} 1$ cells differ from tTregs by their lack of Foxp3 expression and CD25. Both human and mouse $\mathrm{T}_{\mathrm{R}} 1$ cells express lymphocyte activation gene-3 (LAG-3) and CD49b (65). They can express high levels of regulatory molecules such as OX40 (CD134), glucocorticoid-induced tumor necrosis factor receptor (GITR) (66), and inducible T cell costimulator (ICOS) (67).

$\mathrm{T}_{\mathrm{R}} 1$ cells' mechanisms of action include suppression of $\mathrm{T}$ cell and antigen-presenting cell (APC) responses via secretion of IL-10 and TGF- $\beta(64,68)$, death of myeloid APCs via secretion of granzyme and perforin (69), immunomodulation of DC-T cell interactions via secretion of coinhibitory molecules such as CTLA-4, PD-1, and ICOS (70), and production of adenosine through the hydrolysis of ATP by CD39/CD73 expression (71).
$\mathrm{T}_{\mathrm{R}} 1$ cell-based therapeutics have faced some challenges. They can secrete Th1/Th2 cytokines but have limited clonal expansion ability, likely due to the autocrine effects of IL-10. Culturing $\mathrm{T}_{\mathrm{R}} 1$ cells in the presence of dexamethasone and vitamin $\mathrm{D}_{3}$ can facilitate differentiation into a regulatory phenotype (72). Their reduced clonal expansion can be overcome by culture in the presence of either IL-10-producing DCs, IL-27, or aryl hydrocarbon receptor (AHR) agonists (73). Although $\mathrm{T}_{\mathrm{R}} 1$ cells can modulate immune responses primarily by their production of IL-10 and TGF- $\beta$, we speculate that these cells have important reparative mechanisms by modulating other cells involved in regeneration. IL-10 has been shown to modulate macrophage phenotype and promote muscle growth and regeneration (74), it mediates mucosal repair by epithelial WNT1-inducible signaling protein (75), and promotes wound healing via fibroblast/STAT3 signaling. Although IL-10 has been administered to patients with inflammatory bowel disease (IBD) and proven to be safe. However, patient outcomes have been disappointing. The short half-life of IL-10, subtherapeutic doses at mucosal surfaces after systemic administration, and variability between individuals in 


\section{Table 2. Selection of T cell reparative roles in CNS, heart, lung, and kidney models of injury}

\begin{tabular}{|c|c|c|c|}
\hline Organ & Model & Cell type & Comment on mechanism (reference) \\
\hline \multirow[t]{2}{*}{ CNS } & Cuprizone-induced demyelination & Tregs & Promoted oligodendrocyte differentiation and myelin regeneration via CCN3 (137) \\
\hline & Spinal cord contusion & Tregs & Promoted M2 macrophages (138) \\
\hline \multirow[t]{2}{*}{ Heart } & Myocardial infarction & Tregs & CC5R-induced Treg recruitment (139) \\
\hline & & & CD39-dependent cardioprotection (140) \\
\hline \multirow[t]{5}{*}{ Lung } & LPS-induced ALI & Tregs & $\begin{array}{l}\text { Decreased macrophage proinflammatory responses and increased efferocytosis (33, 142); CD73+ Tregs promoted } \\
\text { adenosine-mediated resolution (143); Tregs inhibited fibrocyte recruitment via CXCL12 reduction (144) }\end{array}$ \\
\hline & H5N1 infection & & Treg-derived AREG protected against tissue damage (40) \\
\hline & LPS or left-lung pneumonectomy & & Treg-derived KGF increased lung epithelial cell proliferation (44) \\
\hline & ALI and cell culture & & $\begin{array}{l}\text { Treg-derived AREG or CD103 increased proliferation of damaged type II AECs and promoted their differentiation } \\
\text { into type I AECS (56) }\end{array}$ \\
\hline & ALI (LPS injection) & $\gamma \delta$ T cells & $\gamma \delta$ T cell-derived IL-4 regulated proinflammatory M1 macrophage expansion via TNF- $\alpha$ (146) \\
\hline \multirow[t]{3}{*}{ Kidney } & IRI-induced AKI & Tregs & $\begin{array}{l}\text { Tregs increase IL-10 (35); CD73+ Tregs provided adenosine-mediated protection (147); PD-L1 and PD-L2 } \\
\text { protected from IRI (148); anti-CTLA-4 suppressed Treg-mediated protection (149); antagonists of P2X7R ATP } \\
\text { receptors ameliorated AKI (150) }\end{array}$ \\
\hline & Cisplatin-induced nephrotoxicity & & Tregs decreased TNF- $\alpha$ and IL-1 $\beta$ (151) \\
\hline & IRI-induced AKI & DN T cells & DN T cells ameliorated ischemic kidney injury and expanded after ischemia, increasing IL-10 and IL-27 (100) \\
\hline
\end{tabular}

ALI, acute lung injury; AEC, alveolar epithelial cell; AKI, acute kidney injury; AMP, antimicrobial peptide.

IL-10 receptor or signaling pathway polymorphisms are among possible explanations for the lack of IL-10 efficacy (76).

Therapeutic benefits of $\mathrm{T}_{\mathrm{R}} 1$ have been shown in models of colitis, transplantation, and GvHD $(64,77)$, underscoring the need for IL-10-producing cells and not merely the antiinflammatory cytokine. Administration of antigen-specific $\mathrm{T}_{\mathrm{R}} 1$ cells to refractory Crohn's disease patients has been reported to be well tolerated with dose-related efficacy (78).

\section{CD4+IL-22+ cells}

IL-22 can be produced by several immune cells, including CD $4^{+}$ T cells (Th22 cells), innate lymphoid cells (ILC2 cells), and, less commonly, $\gamma \delta \mathrm{T}$ cells, natural killer T cells (NKT cells), and CD8 ${ }^{+}$ $\mathrm{T}$ cells (79). IL-22 is unique among cytokines, because it is secreted by immune cells, but its action occurs primarily in nonimmune epithelial cells and fibroblasts that express the IL-22 receptor (IL-22R1) (80). CD4+ Th22 cells require ROR $\gamma \mathrm{t}$ and AHR expression, and they also express CCR10 and CCR4, which can direct them in the skin (81). Other $\mathrm{CD}^{+}$populations that can secrete IL-22 include Th1 and Th17 cells (82). The latter express CCR6 and CCR 4 and can be found in the intestine, lung, and skin.

IL-22 displays potent protective and reparative functions. It has been well studied in mucosal barriers in the lungs and gastrointestinal tract for its role in protection against bacteria, viruses, and parasites (83). IL-22 plays a role in barrier integrity during invasion of pathogens: IL-22 can work synergistically with other cytokines such as IL-17 to promote the production of endogenous antimicrobial peptides important in host defense in the skin, airways, and intestine (82). Additionally, IL-22 can promote wound healing by enhancing epithelial migration, differentiation, and proliferation, in part by inducing antiapoptotic molecules (Bcl-2, $\mathrm{Bcl}-\mathrm{xL}$ ) and cell cycle and proliferation proteins (c-Myc, cyclin D1, CDK4) (84-86). IL-22's roles in wound healing (87), pancreatic $\beta$ cell and liver regeneration $(88,89)$, protection against lung and liver fibrosis $(90,91)$, and other functions underscore its widespread importance in tissue protection and repair. However, dysregulated and uncontrolled expression of IL-22 can lead to chronic inflammation and contribute to tissue damage, as seen in psoriasis and atopic dermatitis, and has been linked with the development of several types of neoplasia (92).

A placebo-controlled study to evaluate safety, tolerability, immunogenicity, and pharmacokinetics of intravenous IL-22Fc (an antibody-modified IL-22 fusion protein registered under the name UTTR1147A; NCT02749630) in healthy volunteers, IBD patients, and gastrointestinal GvHD patients (NCT02406651) is under way. Conversely, trials of IL-22 antibody blockade are ongoing for psoriasis and atopic dermatitis (NCT01941537).

\section{CD4-CD8- double-negative $\alpha \beta$ T cells}

CD4-CD8 ${ }^{-}$double-negative (DN) $\alpha \beta$ T cells are an unconventional subset of $\mathrm{T}$ cells with increasingly recognized antiinflammatory and pro-reparative potential. DN T cells can be found in peripheral blood and lymphoid organs in relatively small numbers. However, they represent a substantial fraction 


\section{Table 3. Selection of T cell reparative roles in liver, gastrointestinal, muscle, skin, and bone models of injury}

\begin{tabular}{|c|c|c|c|}
\hline Organ & Model & Cell type & Comment on mechanism (reference) \\
\hline \multirow{5}{*}{ Liver } & Poly:C/d-GaIN-induced fulminant hepatitis & & Mediated increases in TCF- $\beta$ and Kupffer cell-derived IL-10 (153) \\
\hline & Chronic HCV infection ${ }^{A}$ & CD8 ${ }^{+}$Tregs & IL-10-secreting CD8+ Tregs reduced hepatocellular apoptosis, but impaired viral clearance (120) \\
\hline & Concavalin A-induced hepatitis & $\mathrm{T}_{\mathrm{R}} 1$ & Increased IL-10 and decreased TNF- $\alpha$ and IFN- $\gamma$ (156) \\
\hline & HBV infection ${ }^{A}$ (mice and humans) & & Proinflammatory role in HBV viral infection (157) \\
\hline & $\mathrm{CCl}_{4}$-induced liver fibrosis & $\gamma \delta$ T cells & CCR6-dependent recruitment of IL-17+IL-22 $\gamma \delta$ T cells reduced hepatic inflammation and fibrosis (158) \\
\hline \multirow[t]{2}{*}{$\mathrm{Gl}$} & Intestinal epithelial carcinoma cells & Th22/IL-22 ${ }^{+} \mathrm{T}$ cells & Increased expression of AMPs (79) \\
\hline & Colonic epithelial cells & & Upregulated mucin 1, 3, 10, and 13 (159) \\
\hline Muscle & Dystrophy model & & Treg-derived AREG enhanced satellite cell differentiation and muscle repair (51) \\
\hline \multirow[t]{3}{*}{ Skin } & Wound healing & Tregs & $\begin{array}{l}\text { Decreased IFN- } \gamma \text { production by effector T cells, reduced M1 macrophage accumulation, increased EGFR } \\
\text { expression, reduced infiltration and increased apoptosis of neutrophils to shorten the inflammatory } \\
\text { response (163) }\end{array}$ \\
\hline & Human keratinocytes ${ }^{A}$ & Th22/IL-22 ${ }^{\top}$ T cells & $\begin{array}{l}\text { IL-22 in T cell dermatosis patient skin (164); increased AMPs/proinflammatory gene expression and } \\
\text { decreased keratinocyte differentiation gene expression (165); mediated psoriasis-like morphological } \\
\text { changes (166); slight elevation in CXCL1, 2, 5, and } 8 \text { (167); slight decrease in CCL22 and increase } \\
\text { in IL-20 (168) }\end{array}$ \\
\hline & Mouse skin & $\gamma \delta$ T cells & $\begin{array}{l}\text { Murine DETCs have multiple roles in epithelial homeostasis (104, 109, 169, 170); produced KCFs to indirectly } \\
\text { drive macrophage recruitment (110); produced IGF-1, increasing survival of epithelial cells in wounds (111); } \\
\text { regulated keratinocyte AMP production (107) }\end{array}$ \\
\hline
\end{tabular}

AMPs, antimicrobial proteins; HCV, hepatitis C virus; GI, gastrointestinal; IEL, intraepithelial lymphocyte. AHuman data.

in nonlymphoid tissues, e.g., lung, liver, and kidney (93), and can be detected in high numbers in mucosal tissue, e.g., gut epithelia (94) and female reproductive tract (95). Their potential in immune regulation has been described in various settings: graft tolerance (96), autoimmunity (97), and cancer (ref. 98 and Table 1). The predominant antiinflammatory mechanisms ascribed to DN T cells are secretion of IL-10 (97) and cytolysis by granzymes and perforins (98). However, in systemic lupus erythematosus, IL-17-producing DN cells have been associated with an adverse effect (ref. 99 and Table 1).

In mouse kidneys, a large proportion $(25 \%)$ of $\mathrm{T}$ cells are $\mathrm{DN} \alpha \beta \mathrm{T}$ cells, which are also prominent in human kidneys, but to a lesser extent. Two different types of renal DN $\alpha \beta$ T cells have been described: an MHC-independent programmed cell death protein-1 receptor ${ }^{+}\left(\mathrm{PD}-1^{+}\right)$subset and an MHC class Idependent $\mathrm{NK} 1.1^{+}$subset. DN $\alpha \beta$ T cells ameliorate ischemic kidney injury and expand after ischemia. More specifically, the PD-1 subset is highly responsive under ischemia/reperfusion injury (IRI) conditions $(100,101)$.
IL-2 is required for DN $\alpha \beta$ cell activation and function as well as $\mathrm{DN} \alpha \beta$ cell proliferation during the steady state (101). In vitro $\mathrm{T}$ cell function is suppressed by DN $\alpha \beta$ T cells (100). Additionally, kidney-resident DN $\alpha \beta$ T cells showed sizable expression of the antiinflammatory cytokines IL-10 and IL-27 in steady state at the mRNA and protein levels. Three hours after IRI, an increase of IL-10 and a decrease of IL-27 were found (ref. 100 and Table 2).

Other data suggest an aggravation of inflammatory processes by $\mathrm{DN} \alpha \beta \mathrm{T}$ cells. In a stroke mouse model, DN cells were found to cause an exacerbation of ischemic brain injury (102). However, this study did not distinguish different DN T cell subtypes, so the analyzed population might not be limited to DN T cells with $\alpha \beta$ TCR. To date, no specific marker has been found for DN T cells, which makes it difficult to compare different studies and easy for results to be misinterpreted owing to possible contamination of other immune cell types.

Thus, DN $\alpha \beta$ T cells are a very promising T cell subset to put the brakes on inflammation and accelerate repair. Recently, adoptive transfer of allogeneic DN T cells has been shown to be safe 
and efficacious for potential treatment for patients with acute myeloid leukemia and could be considered as a cellular therapy to accelerate organ repair (103).

\section{$\gamma \delta$ T cells}

$\gamma \delta$ T cells represent a small fraction ( $1 \%-5 \%)$ of circulating $\mathrm{T}$ cells in the blood and secondary lymphoid organs (104), but can be present in higher proportions in epithelial tissues in the skin, gastrointestinal tract, and reproductive tract (105). Thus they are well positioned to be involved in epithelial barrier function, repair, and homeostasis, and there is evidence that they do so in a tissue-specific manner.

The murine skin epidermal layer contains Langerhans cells and $\mathrm{T}$ cells. The majority of the $\mathrm{T}$ cells arise from highly specialized $\gamma \delta \mathrm{T}$ cells termed dendritic epidermal T cells (DETCs). Although a human equivalent of DETCs is yet unknown, the human epidermis houses both $\gamma \delta$ and $\alpha \beta$ T cells (106-108). After sensing stress or damage, activated DETCs produce IGF-1, KGF, and KGF2, which promote keratinocyte proliferation and wound healing. DETCs can also produce IL-17A, which can stimulate the induction of the antimicrobial peptide regenerating islet-derived protein $3 \gamma$ (REG3 $\gamma$ ) and $\beta$-defensin, which provide antimicrobial protection and mediate re-epithelialization of the skin (106). In the intestine, $\gamma \delta$ intraepithelial lymphocytes have been shown to produce TGF- $\beta 1$, which reduced the expression of IFN- $\gamma$ from intestinal $\alpha \beta$ cells to dampen inflammation in addition to their role in promoting tissue repair $(105,109-111)$.

In summary, subsets of $\gamma \delta$ T cells are poised to perform tissue-specific roles in inflammation and repair. While the full spectrum of factors that shape $\gamma \delta$ T cell activity is not known, specific butyrophilin-like (BTNL) molecules that are expressed in different epithelial tissues could shape, expand, and mature tissue-specific $\gamma \delta$ T cells (112).

\section{CD8+ Tregs}

It has been several decades since $\mathrm{CD} 8^{+}$Tregs were first described as regulators of immune responses (113). However, the interest in these cells has been relatively muted compared with that in $\mathrm{CD} 4^{+}$ Tregs. Different $\mathrm{CD}^{+}$Treg subsets have been described, and there is growing evidence of their role in autoimmune diseases, cancer, and chronic infections (114-116).

No specific marker for $\mathrm{CD}^{+}$Tregs has been identified to date, making it difficult to compare different studies. The three main subpopulations described and explored are CD28-/lo/+ CD $8^{+}$Tregs (115); CD $122^{+} \mathrm{CD}^{+}$Tregs (mouse), CXCR3 ${ }^{+} \mathrm{CD} 8^{+}$Tregs (human) (117); and Qa-1-restricted CD8+ Tregs (mouse), HLA-E-restricted $\mathrm{CD}^{+}$Tregs (human) (Table 1 ).

There are limited data regarding the role of $\mathrm{CD}^{+}$Tregs in injury and repair. In a murine model of stroke, treatment with IL-10producing $\mathrm{B}$ cells resulted in generation of a dominant $\mathrm{IL}-10^{+}$ $\mathrm{CD}^{+} \mathrm{CD} 122^{+}$Treg population that was associated with decreasing inflammatory responses in brain to a greater extent than were $\mathrm{CD}^{+}$Tregs. Thus, CD8 ${ }^{+}$Tregs might have overlapping function with $C D 4^{+}$Tregs (118).

Nevertheless, functions of CD8 ${ }^{+}$Tregs might not be entirely beneficial. In an acute lung injury model involving H5N1 influenza virus infection, IL- $10^{+} \mathrm{Foxp}^{+} \mathrm{CD}^{+} \mathrm{T}$ cell-mediated suppression of $\mathrm{CD}^{+}$effector $\mathrm{T}$ cell responses led to an increase in mortality (119). However, the effects of regulatory functions of $\mathrm{IL}-10^{+} \mathrm{Foxp}^{+} \mathrm{CD}^{+} \mathrm{T}$ cells in lung injury versus viral infection have not yet been elucidated (119). Additionally, because of the lack of a specific marker for CD $8^{+}$Tregs, the results of different studies cannot be clearly compared and interpreted. In patients with chronic hepatitis $C$ virus infection, IL-10-producing $\mathrm{CD}^{+} \mathrm{T}$ cells have been reported to reduce hepatocellular apoptosis, suggesting that the $\mathrm{CD}^{+} \mathrm{T}$ cells have regulatory functions. However, a detailed immunophenotyping of the $\mathrm{CD}^{+} \mathrm{T}$ cells was not performed in this study (120). Further research will be needed to investigate the role of $\mathrm{CD}^{+}$Tregs in injury and repair processes.

\section{Concluding remarks}

An emerging body of work supports the important role for T cells in resolution of inflammation and organ repair. The most studied $\mathrm{T}$ cell implicated in organ repair has been the $\mathrm{CD} 4^{+} \mathrm{Foxp}^{+}$Treg. However, data support an important role for $\mathrm{T}_{\mathrm{R}} 1$ cells, CD8 $8^{+}$Tregs, CD $4^{+} \mathrm{IL}-22^{+} \mathrm{T}$ cells, CD $4^{-} \mathrm{CD} 8^{-} \mathrm{DN} \alpha \beta \mathrm{T}$ cells, and $\gamma \delta \mathrm{T}$ cells. Other innate lymphoid T cells such as ILC2 cells, invariant NKT cells, and mucosal-associated invariant T (MAIT) cells have important immune-regulatory functions and can display substantial repair and regeneration effects (121). These cells will be covered in another article in this JCI Review series on reparative immunology.

Given the relatively low numbers of these T cells compared with their powerful actions, it is likely that they use both soluble and contact-dependent mediators and work through other cell types. Increasing numbers or enhanced function of specific pro-repair $\mathrm{T}$ cells will likely represent the next generation of therapeutics for organ repair. This approach will need to be personalized, and several factors will have to be considered, including specific organ involvement, the underlying cause and stage of organ injury (e.g., sterile versus infectious and acute versus chronic), the need for polyclonal versus antigen-specific $\mathrm{T}$ cells, their chemokine and homing receptor repertoire (to target the specific injured organ), and mechanisms to modulate their pro-repair $\mathrm{T}$ cell lineage commitment via epigenetic and metabolic reprogramming. Ex vivo "conditioning" of autologous specific $\mathrm{T}$ cells with repair function (via cytokines, drugs, viral transduction, or gene editing) or expanded engineered $\mathrm{T}$ cells (with a reparative armamentarium) will need to be studied as cellular adoptive transfer therapy to promote resolution of inflammation and organ repair.

\section{Acknowledgments}

The authors appreciate the support of National Heart, Lung, and Blood Institute grant HL131812 (to FRD), a Dr. Werner Jackstädt Foundation scholarship (project number S 134-10.117 to JTK), and National Institute of Diabetes and Digestive and Kidney Diseases grants R01DK111209 and R01DK104662 (to HR).

Address correspondence to: Franco R. D’Alessio, Johns Hopkins University School of Medicine and Johns Hopkins Hospital, 5501 Hopkins Bayview Circle, Asthma and Allergy Center, Baltimore, Maryland 21205, USA. Phone: 410.550.4887; Email: fdaless2@jhmi.edu. 
1. Huang WC, Yang CC, Chen IH, Liu YM, Chang SJ, Chuang YJ. Treatment of glucocorticoids inhibited early immune responses and impaired cardiac repair in adult zebrafish. PLoS One. 2013;8(6):e66613.

2. Serhan CN, et al. Resolution of inflammation: state of the art, definitions and terms. FASEB J. 2007;21(2):325-332.

3. Kumar BV, Connors TJ, Farber DL. Human T cell development, localization, and function throughout life. Immunity. 2018;48(2):202-213.

4. Gieseck RL, Wilson MS, Wynn TA. Type $2 \mathrm{immu-}$ nity in tissue repair and fibrosis. Nat Rev Immunol. 2018;18(1):62-76.

5. Pulendran B, Artis D. New paradigms in type 2 immunity. Science. 2012;337(6093):431-435.

6. Vignali DA, Collison LW, Workman CJ. How regulatory T cells work. Nat Rev Immunol. 2008;8(7):523-532.

7. Shevach EM. Mechanisms of Foxp $3^{+} \mathrm{T}$ regulatory cell-mediated suppression. Immunity. 2009;30(5):636-645.

8. Tan QKG, Louie RJ, Sleasman JW. IPEX syndrome. In: Adam MP, et al., eds. GeneReviews. Seattle, Washington, USA: 1993.

9. Ochs HD, Gambineri E, Torgerson TR. IPEX, FOXP3 and regulatory T-cells: a model for autoimmunity. Immunol Res. 2007;38(1-3):112-121.

10. Bennett CL, Ochs HD. IPEX is a unique X-linked syndrome characterized by immune dysfunction, polyendocrinopathy, enteropathy, and a variety of autoimmune phenomena. Curr Opin Pediatr. 2001;13(6):533-538.

11. Clark LB, Appleby MW, Brunkow ME, Wilkinson JE, Ziegler SF, Ramsdell F. Cellular and molecular characterization of the scurfy mouse mutant. JImmunol. 1999;162(5):2546-2554.

12. Miyara M, et al. Functional delineation and differentiation dynamics of human $\mathrm{CD} 4^{+} \mathrm{T}$ cells expressing the FoxP3 transcription factor. Immunity. 2009;30(6):899-911.

13. Abbas AK, et al. Regulatory T cells: recommendations to simplify the nomenclature. Nat Immunol. 2013;14(4):307-308.

14. Tone Y, Furuuchi K, Kojima Y, Tykocinski ML, Greene MI, Tone M. Smad3 and NFAT cooperate to induce Foxp3 expression through its enhancer. Nat Immunol. 2008;9(2):194-202.

15. Schmitt EG, Williams CB. Generation and function of induced regulatory T cells. Front Immunol. 2013;4:152.

16. Zheng Y, Josefowicz S, Chaudhry A, Peng XP, Forbush K, Rudensky AY. Role of conserved non-coding DNA elements in the Foxp3 gene in regulatory T-cell fate. Nature. 2010;463(7282):808-812.

17. Himmel ME, MacDonald KG, Garcia RV, Steiner TS, Levings MK. Helios ${ }^{+}$and Helios- cells coexist within the natural FOXP3 ${ }^{+} \mathrm{T}$ regulatory cell subset in humans. JImmunol. 2013;190(5):2001-2008.

18. Yadav M, et al. Neuropilin-1 distinguishes natural and inducible regulatory $\mathrm{T}$ cells among regulatory T cell subsets in vivo. J Exp Med. 2012;209(10):1713-1722, S1-S19.

19. Floess $S$, et al. Epigenetic control of the foxp3 locus in regulatory T cells. PLoS Biol. 2007;5(2):e38.

20. Tadokoro CE, et al. Regulatory T cells inhibit sta- ble contacts between $\mathrm{CD} 4^{+} \mathrm{T}$ cells and dendritic cells in vivo. JExp Med. 2006;203(3):505-511.

21. Oderup C, Cederbom L, Makowska A, Cilio CM, Ivars F. Cytotoxic T lymphocyte antigen-4-dependent down-modulation of costimulatory molecules on dendritic cells in $\mathrm{CD} 44^{+} \mathrm{CD} 25^{+}$regulatory T-cell-mediated suppression. Immunology. 2006;118(2):240-249.

22. Huang CT, et al. Role of LAG-3 in regulatory $T$ cells. Immunity. 2004;21(4):503-513.

23. Fallarino F, et al. Modulation of tryptophan catabolism by regulatory T cells. Nat Immunol. 2003;4(12):1206-1212.

24. Cederbom L, Hall H, Ivars F. CD4 ${ }^{+} \mathrm{CD} 25^{+}$regulatory $\mathrm{T}$ cells down-regulate co-stimulatory molecules on antigen-presenting cells. Eur J Immunol. 2000;30(6):1538-1543.

25. Pandiyan P, Zheng L, Ishihara S, Reed J, Lenardo MJ. CD $4^{+} \mathrm{CD} 25^{+} \mathrm{Foxp}^{+}$regulatory T cells induce cytokine deprivation-mediated apoptosis of effector $\mathrm{CD} 4^{+} \mathrm{T}$ cells. Nat Immunol. 2007;8(12):1353-1362.

26. Deaglio $S$, et al. Adenosine generation catalyzed by CD39 and CD73 expressed on regulatory $\mathrm{T}$ cells mediates immune suppression. J Exp Med. 2007;204(6):1257-1265.

27. Kobie JJ, Shah PR, Yang L, Rebhahn JA, Fowell DJ, Mosmann TR. T regulatory and primed uncommitted CD4 $\mathrm{T}$ cells express $\mathrm{CD} 73$, which suppresses effector $\mathrm{CD} 4 \mathrm{~T}$ cells by converting 5 '-adenosine monophosphate to adenosine. JImmunol. 2006;177(10):6780-6786.

28. Loebbermann J, et al. Regulatory T cells expressing granzyme $\mathrm{B}$ play a critical role in controlling lung inflammation during acute viral infection. Mucosal Immunol. 2012;5(2):161-172.

29. Velaga S, et al. Granzyme A is required for regulatory T-cell mediated prevention of gastrointestinal graft-versus-host disease. PLoS One. 2015;10(4):e0124927.

30. Sula Karreci E, et al. Human regulatory T cells undergo self-inflicted damage via granzyme pathways upon activation. JCI Insight. 2017;2(21):91599.

31. Kearley J, Barker JE, Robinson DS, Lloyd CM. Resolution of airway inflammation and hyperreactivity after in vivo transfer of CD4+CD25+ regulatory $\mathrm{T}$ cells is interleukin 10 dependent. JExp Med. 2005;202(11):1539-1547.

32. Rubtsov YP, et al. Regulatory $\mathrm{T}$ cell-derived interleukin-10 limits inflammation at environmental interfaces. Immunity. 2008;28(4):546-558.

33. D’Alessio FR, et al. CD $4^{+} \mathrm{CD} 25^{+}{ }^{\mathrm{F}}$ oxp $3^{+}$Tregs resolve experimental lung injury in mice and are present in humans with acute lung injury. JClin Invest. 2009;119(10):2898-2913.

34. Asseman C, Mauze S, Leach MW, Coffman RL, Powrie F. An essential role for interleukin 10 in the function of regulatory $\mathrm{T}$ cells that inhibit intestinal inflammation. J Exp Med. 1999;190(7):995-1004.

35. Kinsey GR, et al. Regulatory T cells suppress innate immunity in kidney ischemia-reperfusion injury. J Am Soc Nephrol. 2009;20(8):1744-1753.

36. Ostroukhova $\mathrm{M}$, et al. Tolerance induced by inhaled antigen involves $\mathrm{CD} 4(+) \mathrm{T}$ cells expressing membrane-bound TGF- $\beta$ and FOXP3. JClin Invest. 2004;114(1):28-38.
37. Ostroukhova M, Qi Z, Oriss TB, Dixon-McCarthy B, Ray P, Ray A. Treg-mediated immunosuppression involves activation of the Notch-HES1 axis by membrane-bound TGF- $\beta$. J Clin Invest . 2006;116(4):996-1004.

38. Collison LW, et al. IL-35-mediated induction of a potent regulatory T cell population. Nat Immunol. 2010;11(12):1093-1101.

39. Tidball JG. Regulation of muscle growth and regeneration by the immune system. Nat Rev Immunol. 2017;17(3):165-178.

40. Arpaia N, et al. A distinct function of regulatory T cells in tissue protection. Cell. 2015;162(5):1078-1089.

41. Zaiss DM, et al. Amphiregulin enhances regulatory $\mathrm{T}$ cell-suppressive function via the epidermal growth factor receptor. Immunity. 2013;38(2):275-284.

42. Qi Y, Operario DJ, Georas SN, Mosmann TR. The acute environment, rather than $\mathrm{T}$ cell subset pre-commitment, regulates expression of the human T cell cytokine amphiregulin. PLoS One. 2012;7(6):e39072.

43. Zaiss DMW, Gause WC, Osborne LC, Artis D. Emerging functions of amphiregulin in orchestrating immunity, inflammation, and tissue repair. Immunity. 2015;42(2):216-226.

44. Dial CF, Tune MK, Doerschuk CM, Mock JR. Foxp $3^{+}$regulatory $\mathrm{T}$ cell expression of keratinocyte growth factor enhances lung epithelial proliferation. Am J Respir Cell Mol Biol. 2017;57(2):162-173.

45. D’Alessio FR, Zhong Q, Jenkins J, Moldobaeva A, Wagner EM. Lung angiogenesis requires $\mathrm{CD} 4(+)$ forkhead homeobox protein-3(+) regulatory T cells. Am J Respir Cell Mol Biol. 2015;52(5):603-610.

46. Leung OM, et al. Regulatory T cells promote apelin-mediated sprouting angiogenesis in type 2 diabetes. Cell Rep. 2018;24(6):1610-1626.

47. Tiemessen MM, Jagger AL, Evans HG, van Herwijnen MJ, John S, Taams LS. CD $4{ }^{+} \mathrm{CD} 25^{+}{ }^{+}$oxp $^{+}$ regulatory $\mathrm{T}$ cells induce alternative activation of human monocytes/macrophages. Proc Natl Acad Sci U S A. 2007;104(49):19446-19451.

48. Liew FY, Girard JP, Turnquist HR. Interleukin-33 in health and disease. Nat Rev Immunol. 2016;16(11):676-689.

49. Schiering C, et al. The alarmin IL-33 promotes regulatory T-cell function in the intestine. Nature. 2014;513(7519):564-568.

50. Peine M, Marek RM, Löhning M. IL-33 in T cell differentiation, function, and immune homeostasis. Trends Immunol. 2016;37(5):321-333.

51. Burzyn D, et al. A special population of regulatory $\mathrm{T}$ cells potentiates muscle repair. Cell. 2013;155(6):1282-1295.

52. Liu Q, et al. IL-33-mediated IL-13 secretion by $\mathrm{ST}^{+}$Tregs controls inflammation after lung injury. JCI Insight. 2019;4(6):123919.

53. Chen WY, Tsai TH, Yang JL, Li LC. Therapeutic strategies for targeting IL-33/ST2 signalling for the treatment of inflammatory diseases. Cell Physiol Biochem. 2018;49(1):349-358.

54. Kuswanto W, et al. Poor repair of skeletal muscle in aging mice reflects a defect in local, interleukin-33-dependent accumulation of regulatory $\mathrm{T}$ cells. Immunity. 2016;44(2):355-367.

55. Stremska ME, et al. IL233, a novel IL-2 and IL-33 
hybrid cytokine, ameliorates renal injury. JAm Soc Nephrol. 2017;28(9):2681-2693.

56. Mock JR, et al. Foxp $3^{+}$regulatory $\mathrm{T}$ cells promote lung epithelial proliferation. Mucosal Immunol. 2014;7(6):1440-1451.

57. Tan W, Zhang C, Liu J, Miao Q. Regulatory T-cells promote pulmonary repair by modulating $\mathrm{T}$ helper cell immune responses in lipopolysaccharide-induced acute respiratory distress syndrome. Immunology. 2019;157(2):151-162.

58. Ali N, et al. Regulatory T cells in skin facilitate epithelial stem cell differentiation. Cell. 2017;169(6):1119-1129.e11.

59. Singer BD, King LS, D’Alessio FR. Regulatory T cells as immunotherapy. Front Immunol. 2014;5:46.

60. Bluestone JA, Tang Q. Treg cells-the next frontier of cell therapy. Science. 2018;362(6411):154-155.

61. Koreth J, et al. Interleukin-2 and regulatory $\mathrm{T}$ cells in graft-versus-host disease. $N$ Engl J Med. 2011;365(22):2055-2066.

62. Matta BM, Turnquist HR. Expansion of regulatory T cells in vitro and in vivo by IL-33. Methods Mol Biol. 2016;1371:29-41.

63. Singer BD, et al. Regulatory T cell DNA methyltransferase inhibition accelerates resolution of lung inflammation. Am J Respir Cell Mol Biol. 2015;52(5):641-652.

64. Groux H, et al. A CD4 $4^{+}$T-cell subset inhibits antigen-specific T-cell responses and prevents colitis. Nature. 1997;389(6652):737-742.

65. Gagliani N, et al. Coexpression of CD49b and LAG-3 identifies human and mouse $\mathrm{T}$ regulatory type 1 cells. Nat Med. 2013;19(6):739-746.

66. Cobbold SP, et al. Regulatory T cells and dendritic cells in transplantation tolerance: molecular markers and mechanisms. Immunol Rev. 2003;196:109-124.

67. Kohyama M, Sugahara D, Sugiyama S, Yagita H, Okumura K, Hozumi N. Inducible costimulator-dependent IL-10 production by regulatory $\mathrm{T}$ cells specific for self-antigen. Proc Natl Acad Sci U S A. 2004;101(12):4192-4197.

68. Gregori S, et al. Differentiation of type $1 \mathrm{~T}$ regulatory cells (Tr1) by tolerogenic DC-10 requires the IL-10-dependent ILT4/HLA-G pathway. Blood. 2010;116(6):935-944.

69. Magnani CF, et al. Killing of myeloid APCs via HLA class I, CD2 and CD226 defines a novel mechanism of suppression by human Tr1 cells. Eur J Immunol. 2011;41(6):1652-1662.

70. Gregori S, Goudy KS, Roncarolo MG. The cellular and molecular mechanisms of immuno-suppression by human type 1 regulatory T cells. Front Immunol. 2012;3:30.

71. Schuler PJ, et al. Human $\mathrm{CD} 4^{+} \mathrm{CD} 39^{+}$regulatory $\mathrm{T}$ cells produce adenosine upon co-expression of surface $\mathrm{CD} 73$ or contact with $\mathrm{CD} 73+$ exosomes or CD73+ cells. Clin Exp Immunol. 2014;177(2):531-543.

72. Barrat FJ, et al. In vitro generation of interleukin 10-producing regulatory $\mathrm{CD} 4(+) \mathrm{T}$ cells is induced by immunosuppressive drugs and inhibited by Thelper type 1 (Th1)- and Th2-inducing cytokines. JExp Med. 2002;195(5):603-616.

73. Pot C, Apetoh L, Kuchroo VK. Type 1 regulatory T cells (Tr1) in autoimmunity. Semin Immunol. 2011;23(3):202-208.
74. Deng B, Wehling-Henricks M, Villalta SA, Wang Y, Tidball JG. IL-10 triggers changes in macrophage phenotype that promote muscle growth and regeneration. JImmunol.2012;189(7):3669-3680.

75. Quiros M, et al. Macrophage-derived IL-10 mediates mucosal repair by epithelial WISP-1 signaling. J Clin Invest. 2017;127(9):3510-3520.

76. Marlow GJ, van Gent D, Ferguson LR. Why interleukin-10 supplementation does not work in Crohn's disease patients. World J Gastroenterol. 2013;19(25):3931-3941.

77. Gagliani N, et al. Antigen-specific dependence of Tr1-cell therapy in preclinical models of islet transplant. Diabetes. 2010;59(2):433-439.

78. Desreumaux P, et al. Safety and efficacy of antigen-specific regulatory T-cell therapy for patients with refractory Crohn's disease. Gastroenterology. 2012;143(5):1207-1217.e2.

79. Jia L, Wu C. The biology and functions of Th22 cells. Adv Exp Med Biol. 2014;841:209-230.

80. Perusina Lanfranca M, Lin Y, Fang J, Zou W, Frankel T. Biological and pathological activities of interleukin-22. J MolMed. 2016;94(5):523-534.

81. Creery WD, Diaz-Mitoma F, Filion L, Kumar A. Differential modulation of B7-1 and B7-2 isoform expression on human monocytes by cytokines which influence the development of T helper cell phenotype. Eur JImmunol. 1996;26(6):1273-1277.

82. Rutz S, Eidenschenk C, Ouyang W. IL-22, not simply a Th17 cytokine. Immunol Rev. 2013;252(1):116-132.

83. Sonnenberg GF, Fouser LA, Artis D. Border patrol: regulation of immunity, inflammation and tissue homeostasis at barrier surfaces by IL-22. Nat Immunol. 2011;12(5):383-390.

84. Zenewicz LA, Yancopoulos GD, Valenzuela DM, Murphy AJ, Stevens S, Flavell RA. Innate and adaptive interleukin-22 protects mice from inflammatory bowel disease. Immunity. 2008;29(6):947-957.

85. Sun D, et al. Th22 cells control colon tumorigenesis through STAT3 and Polycomb Repression complex 2 signaling. Oncoimmunology. 2016;5(8):e1082704.

86. Wolk K, et al. IL-22 regulates the expression of genes responsible for antimicrobial defense, cellular differentiation, and mobility in keratinocytes: a potential role in psoriasis. Eur J Immunol. 2006;36(5):1309-1323.

87. McGee HM, et al. IL-22 promotes fibroblast-mediated wound repair in the skin. J Invest Dermatol. 2013;133(5):1321-1329.

88. Radaeva S, Sun R, Pan HN, Hong F, Gao B. Interleukin 22 (IL-22) plays a protective role in T cell-mediated murine hepatitis: IL-22 is a survival factor for hepatocytes via STAT3 activation. Hepatology. 2004;39(5):1332-1342.

89. Xue J, Nguyen DT, Habtezion A. Aryl hydrocarbon receptor regulates pancreatic IL-22 production and protects mice from acute pancreatitis. Gastroenterology. 2012;143(6):1670-1680.

90. Simonian PL, Wehrmann F, Roark CL, Born WK, O’Brien RL, Fontenot AP. $\gamma \delta$ T cells protect against lung fibrosis via IL-22. J Exp Med. 2010;207(10):2239-2253

91. Kong X, Feng D, Mathews S, Gao B. Hepatoprotective and anti-fibrotic functions of interleukin-22: therapeutic potential for the treatment of alcoholic liver disease. J Gastroenterol Hepatol. 2013;28(suppl 1):56-60.

92. Zhuang $\mathrm{Y}$, et al. Increased intratumoral IL-22-producing CD4(+) T cells and Th22 cells correlate with gastric cancer progression and predict poor patient survival. Cancer Immunol Immunother. 2012;61(11):1965-1975.

93. Ascon DB, et al. Normal mouse kidneys contain activated and $\mathrm{CD}^{+}{ }^{+} \mathrm{CD} 4^{-} \mathrm{CD} 8^{-}$double-negative $\mathrm{T}$ lymphocytes with a distinct TCR repertoire. JLeukoc Biol. 2008;84(6):1400-1409.

94. Ruscher R, Kummer RL, Lee YJ, Jameson SC, Hogquist KA. CD8 $\alpha \alpha$ intraepithelial lymphocytes arise from two main thymic precursors. Nat Immunol. 2017;18(7):771-779.

95. Johansson M, Lycke N. A unique population of extrathymically derived alpha beta $\mathrm{TCR}^{+} \mathrm{CD} 4$ $\mathrm{CD} 8^{-} \mathrm{T}$ cells with regulatory functions dominates the mouse female genital tract. JImmunol. 2003;170(4):1659-1666.

96. Hillhouse EE, Delisle JS, Lesage S. Immunoregulatory $\mathrm{CD} 4(-) \mathrm{CD} 8(-) \mathrm{T}$ cells as a potential therapeutic tool for transplantation, autoimmunity, and cancer. Front Immunol. 2013;4:6.

97. Duncan B, et al. Double negative ( $\mathrm{CD}^{+} 4-8$-) TCR alphabeta splenic cells from young NOD mice provide long-lasting protection against type 1 diabetes. PLoS One. 2010;5(7):e11427.

98. Voelkl S, Moore TV, Rehli M, Nishimura MI, Mackensen A, Fischer K. Characterization of MHC class-I restricted TCR $\alpha \beta^{-} \mathrm{CD}^{-}{ }^{-} \mathrm{CD} 8^{-}$double negative $\mathrm{T}$ cells recognizing the gp100 antigen from a melanoma patient after gp100 vaccination. Cancer Immunol Immunother. 2009;58(5):709-718.

99. Crispín JC, Tsokos GC. Human TCR- $\alpha \beta^{+}$CD4$\mathrm{CD} 8^{-} \mathrm{T}$ cells can derive from $\mathrm{CD} 8^{+} \mathrm{T}$ cells and display an inflammatory effector phenotype. JImmunol. 2009;183(7):4675-4681.

100.Martina MN, et al. Double-negative $\alpha \beta$ T cells are early responders to AKI and are found in human kidney. J Am Soc Nephrol. 2016;27(4):1113-1123.

101.Sadasivam M, et al. Activation and proliferation of PD-1. JAm Soc Nephrol. 2019;30(2):277-292.

102. Meng H, et al. Double-negative T cells remarkably promote neuroinflammation after ischemic stroke. Proc Natl Acad Sci U S A. 2019;116(12):5558-5563.

103. Lee J, et al. Allogeneic human double negative $T$ cells as a novel immunotherapy for acute myeloid leukemia and its underlying mechanisms. Clin Cancer Res. 2018;24(2):370-382.

104.Allison JP, Havran WL. The immunobiology of $\mathrm{T}$ cells with invariant $\gamma \delta$ antigen receptors. Annu Rev Immunol. 1991;9:679-705.

105. Chen Y, Chou K, Fuchs E, Havran WL, Boismenu R. Protection of the intestinal mucosa by intraepithelial $\gamma \delta \mathrm{T}$ cells. Proc Natl Acad Sci U S A. 2002;99(22):14338-14343.

106. Toulon A, et al. A role for human skin-resident $\mathrm{T}$ cells in wound healing. JExp Med. 2009;206(4):743-750.

107. MacLeod AS, et al. Dendritic epidermal T cells regulate skin antimicrobial barrier function. J Clin Invest. 2013;123(10):4364-4374.

108. Ramirez K, Witherden DA, Havran WL. All hands on $\mathrm{DE}(\mathrm{T}) \mathrm{C}$ : epithelial-resident $\gamma \delta \mathrm{T}$ cells respond to tissue injury. Cell Immunol. 2015;296(1):57-61. 
109. Boismenu R, Havran WL. Modulation of epithelial cell growth by intraepithelial $\gamma \delta$ T cells. Science. 1994;266(5188):1253-1255.

110. Karvinen S, et al. Keratinocyte growth factor stimulates migration and hyaluronan synthesis in the epidermis by activation of keratinocyte hyaluronan synthases 2 and 3. J Biol Chem. 2003;278(49):49495-49504.

111. Sharp LL, Jameson JM, Cauvi G, Havran WL. Dendritic epidermal $\mathrm{T}$ cells regulate skin homeostasis through local production of insulin-like growth factor 1. Nat Immunol. 2005;6(1):73-79.

112. Nielsen MM, Witherden DA, Havran WL. $\gamma \delta$ $\mathrm{T}$ cells in homeostasis and host defence of epithelial barrier tissues. Nat Rev Immunol. 2017;17(12):733-745.

113. Sharma R, Kinsey GR. Regulatory T cells in acute and chronic kidney diseases. Am J Physiol Renal Physiol. 2018;314(5):F679-F698.

114. Dinesh RK, Skaggs BJ, La Cava A, Hahn BH, Singh RP. CD8 ${ }^{+}$Tregs in lupus, autoimmunity, and beyond. Autoimmun Rev. 2010;9(8):560-568.

115. Vuddamalay Y, van Meerwijk JP. CD28(-) and $\mathrm{CD} 28$ (low) CD8(+) regulatory T cells: of mice and men. Front Immunol. 2017;8:31.

116. Yu Y, Ma X, Gong R, Zhu J, Wei L, Yao J. Recent advances in CD8. Oncol Lett. 2018;15(6):8187-8194.

117. Liu J, Chen D, Nie GD, Dai Z. CD8(+)CD122(+) T-cells: a newly emerging regulator with central memory cell phenotypes. Front Immunol. 2015;6:494.

118. Bodhankar S, et al. Regulatory CD8(+)CD122 $(+)$ T-cells predominate in CNS after treatment of experimental stroke in male mice with IL-10-secreting B-cells. Metab Brain Dis. 2015;30(4):911-924.

119. Zou Q, et al. CD8 ${ }^{+}$Treg cells suppress CD8 ${ }^{+}$ $\mathrm{T}$ cell-responses by IL-10-dependent mechanism during $\mathrm{H} 5 \mathrm{~N} 1$ influenza virus infection. Eur J Immunol. 2014;44(1):103-114.

120. Abel M, et al. Intrahepatic virus-specific IL-10-producing CD8 T cells prevent liver damage during chronic hepatitis $\mathrm{C}$ virus infection. Hepatology. 2006;44(6):1607-1616.

121. Vivier E, et al. Innate lymphoid cells: 10 years on. Cell. 2018;174(5):1054-1066.

122. Kanamori M, Nakatsukasa H, Okada M, Lu Q, Yoshimura A. Induced regulatory T cells: their development, stability, and applications. Trends Immunol. 2016;37(11):803-811.

123. Jonuleit $\mathrm{H}$, Schmitt E, Stassen M, Tuettenberg A, Knop J, Enk AH. Identification and functional characterization of human CD4(+)CD25(+) T cells with regulatory properties isolated from peripheral blood. JExp Med. 2001;193(11):1285-1294.

124. Chen W, Ford MS, Young KJ, Zhang L. The role and mechanisms of double negative regulatory $\mathrm{T}$ cells in the suppression of immune responses. Cell Mol Immunol. 2004;1(5):328-335.

125. Young KJ, Kay LS, Phillips MJ, Zhang L. Antitumor activity mediated by double-negative $\mathrm{T}$ cells. Cancer Res. 2003;63(22):8014-8021.

126.Curotto de Lafaille MA, Lafaille JJ. CD4(+) regulatory $\mathrm{T}$ cells in autoimmunity and allergy. Curr Opin Immunol. 2002;14(6):771-778.

127. Wood KJ, Sakaguchi S. Regulatory T cells in transplantation tolerance. Nat Rev Immunol. 2003;3(3):199-210.
128. Hori S, Carvalho TL, Demengeot J. CD $25^{+} \mathrm{CD} 4^{+}$ regulatory $\mathrm{T}$ cells suppress $\mathrm{CD} 4^{+} \mathrm{T}$ cell-mediated pulmonary hyperinflammation driven by Pneumocystis carinii in immunodeficient mice. Eur J Immunol. 2002;32(5):1282-1291.

129. Endharti AT, et al. Cutting edge: $\mathrm{CD} 8^{+} \mathrm{CD} 122^{+}$ regulatory T cells produce IL-10 to suppress IFN- $\gamma$ production and proliferation of $\mathrm{CD} 8^{+} \mathrm{T}$ cells. J Immunol. 2005;175(11):7093-7097.

130. Gol-Ara M, Jadidi-Niaragh F, Sadria R, Azizi G, Mirshafiey A. The role of different subsets of regulatory $\mathrm{T}$ cells in immunopathogenesis of rheumatoid arthritis. Arthritis. 2012;2012:805875.

131. Jeon YW, et al. Enhancement of graft-versus-host disease control efficacy by adoptive transfer of type 1 regulatory T cells in bone marrow transplant model. Stem Cells Dev. 2019;28(2):129-140.

132.Zheng Y, et al. Interleukin-22 mediates early host defense against attaching and effacing bacterial pathogens. Nat Med. 2008;14(3):282-289.

133. Pan HF, Li XP, Zheng SG, Ye DQ. Emerging role of interleukin-22 in autoimmune diseases. Cytokine Growth Factor Rev. 2013;24(1):51-57.

134. Cowley SC, Meierovics AI, Frelinger JA, Iwakura Y, Elkins KL. Lung CD4-CD8- double-negative $\mathrm{T}$ cells are prominent producers of IL-17A and IFN- $\gamma$ during primary respiratory murine infection with Francisella tularensis live vaccine strain. J Immunol. 2010;184(10):5791-5801.

135. Zhao Y, Niu C, Cui J. Gamma-delta $(\gamma \delta)$ T cells: friend or foe in cancer development? J Transl Med. 2018;16(1):3.

136.Zheng J, Liu Y, Lau YL, Tu W. $\gamma \delta$-T cells: an unpolished sword in human anti-infection immunity. Cell Mol Immunol. 2013;10(1):50-57.

137. Dombrowski Y, et al. Regulatory $\mathrm{T}$ cells promote myelin regeneration in the central nervous system. Nat Neurosci. 2017;20(5):674-680.

138. Gadani SP, Walsh JT, Smirnov I, Zheng J, Kipnis J. The glia-derived alarmin IL-33 orchestrates the immune response and promotes recovery following CNS injury. Neuron. 2015;85(4):703-709.

139. Dobaczewski M, Xia Y, Bujak M, Gonzalez-Quesada C, Frangogiannis NG. CCR5 signaling suppresses inflammation and reduces adverse remodeling of the infarcted heart, mediating recruitment of regulatory T cells. Am J Pathol. 2010;176(5):2177-2187.

140.Xia N, et al. Activated regulatory T-cells attenuate myocardial ischaemia/reperfusion injury through a CD39-dependent mechanism. Clin Sci. 2015;128(10):679-693.

141. Weirather J, et al. Foxp $3^{+} \mathrm{CD}^{+} \mathrm{T}$ cells improve healing after myocardial infarction by modulating monocyte/macrophage differentiation. Circ Res. 2014;115(1):55-67.

142. Tang $\mathrm{L}$, et al. Active players in resolution of shock/sepsis induced indirect lung injury: immunomodulatory effects of Tregs and PD-1. J Leukoc Biol. 2014;96(5):809-820.

143. Ehrentraut $\mathrm{H}$, et al. CD73+ regulatory $\mathrm{T}$ cells contribute to adenosine-mediated resolution of acute lung injury. FASEB J. 2013;27(6):2207-2219.

144.Garibaldi BT, et al. Regulatory T cells reduce acute lung injury fibroproliferation by decreasing fibrocyte recruitment. Am J Respir Cell Mol Biol. 2013;48(1):35-43.

145. Aujla SJ, et al. IL-22 mediates mucosal host defense against Gram-negative bacterial pneumonia. Nat Med. 2008;14(3):275-281.

146.Wehrmann $\mathrm{F}$, et al. $\gamma \delta \mathrm{T}$ cells protect against LPS-induced lung injury. J Leukoc Biol. 2016;99(2):373-386.

147. Kinsey GR, et al. Autocrine adenosine signaling promotes regulatory $\mathrm{T}$ cell-mediated renal protection. J Am Soc Nephrol. 2012;23(9):1528-1537.

148.Jaworska K, et al. Both PD-1 ligands protect the kidney from ischemia reperfusion injury. J Iтmunol. 2015;194(1):325-333.

149. Lai LW, Yong KC, Lien YH. Pharmacologic recruitment of regulatory $\mathrm{T}$ cells as a therapy for ischemic acute kidney injury. Kidney Int . 2012;81(10):983-992.

150. Koo TY, et al. The P2X7 receptor antagonist, oxidized adenosine triphosphate, ameliorates renal ischemia-reperfusion injury by expansion of regulatory T cells. Kidney Int. 2017;92(2):415-431.

151. Lee $\mathrm{H}$, et al. $\mathrm{CD} 4{ }^{+} \mathrm{CD} 25^{+}$regulatory $\mathrm{T}$ cells attenuate cisplatin-induced nephrotoxicity in mice. Kidney Int. 2010;78(11):1100-1109.

152. Lu L, et al. In vitro induced CD4(+)CD25(+) Foxp3(+) Tregs attenuate hepatic ischemia-reperfusion injury. Int Immunopharmacol. 2009;9(5):549-552.

153. Hou X, et al. CD4(+)Foxp3(+) Tregs protect against innate immune cell-mediated fulminant hepatitis in mice. Mol Immunol. 2015;63(2):420-427.

154. Boettler T, et al. T cells with a $\mathrm{CD} 4^{+} \mathrm{CD} 25^{+}$regulatory phenotype suppress in vitro proliferation of virus-specific $\mathrm{CD} 8^{+} \mathrm{T}$ cells during chronic hepatitis C virus infection. JVirol. 2005;79(12):7860-7867.

155. Bolacchi F, et al. Increased hepatitis $C$ virus (HCV)-specific $\mathrm{CD} 4{ }^{+} \mathrm{CD} 25^{+}$regulatory $\mathrm{T}$ lymphocytes and reduced $\mathrm{HCV}$-specific $\mathrm{CD} 4^{+} \mathrm{T}$ cell response in HCV-infected patients with normal versus abnormal alanine aminotransferase levels. Clin Exp Immunol. 2006;144(2):188-196.

156. Ye F, et al. Tr1 regulatory $\mathrm{T}$ cells induced by ConA pretreatment prevent mice from ConA-induced hepatitis. Immunol Lett. 2009;122(2):198-207.

157. Zhang $\mathrm{Y}$, et al. A proinflammatory role for interleukin-22 in the immune response to hepatitis B virus. Gastroenterology. 2011;141(5):1897-1906.

158. Hammerich L, et al. Chemokine receptor CCR6-dependent accumulation of $\gamma \delta \mathrm{T}$ cells in injured liver restricts hepatic inflammation and fibrosis. Hepatology. 2014;59(2):630-642.

159. Sugimoto K, et al. IL-22 ameliorates intestinal inflammation in a mouse model of ulcerative colitis. JClin Invest. 2008;118(2):534-544.

160. Brand S, et al. IL-22 is increased in active Crohn's disease and promotes proinflammatory gene expression and intestinal epithelial cell migration. Am J Physiol Gastrointest Liver Physiol. 2006;290(4):G827-G838.

161. Meehan TF, et al. Protection against colitis by CD100-dependent modulation of intraepithelial $\gamma \delta \mathrm{T}$ lymphocyte function. Mucosal Immunol. 2014;7(1):134-142.

162.Panduro M, Benoist C, Mathis D. $\mathrm{T}_{\text {reg }}$ cells limit IFN- $\gamma$ production to control macrophage accrual and phenotype during skeletal muscle regeneration. Proc Natl Acad Sci U S A. 2018;115(11):E2585-E2593.

163. Nosbaum A, et al. Cutting edge: regulatory $\mathrm{T}$ cells facilitate cutaneous wound healing. JImmunol. 
2016;196(5):2010-2014.

164. Wolk K, Kunz S, Witte E, Friedrich M, Asadullah $\mathrm{K}$, Sabat R. IL-22 increases the innate immunity of tissues. Immunity. 2004;21(2):241-254.

165. Boniface K, Bernard FX, Garcia M, Gurney AL, Lecron JC, Morel F. IL-22 inhibits epidermal differentiation and induces proinflammatory gene expression and migration of human keratinocytes. JImmunol. 2005;174(6):3695-3702.

166. Wolk K, et al. IL-22 and IL-20 are key mediators of the epidermal alterations in psoriasis while IL-17 and IFN- $\gamma$ are not. J Mol Med. 2009;87(5):523-536.

167. Sa SM, et al. The effects of IL-20 subfamily cytokines on reconstituted human epidermis suggest potential roles in cutaneous innate defense and pathogenic adaptive immunity in psoriasis. Jimmunol. 2007;178(4):2229-2240.

168. Wolk K, et al. The Th17 cytokine IL-22 induces IL-20 production in keratinocytes: a novel immunological cascade with potential relevance in psoriasis. Eur JImmunol. 2009;39(12):3570-3581.

169. Boismenu R, Feng L, Xia YY, Chang JC, Havran WL. Chemokine expression by intraepithelial $\gamma \delta$ T cells. Implications for the recruitment of inflammatory cells to damaged epithelia. JImmunol. 1996;157(3):985-992.

170. Jameson JM, Cauvi G, Sharp LL, Witherden DA, Havran WL. Gammadelta T cell-induced hyaluronan production by epithelial cells regulates inflammation. JExp Med. 2005;201(8):1269-1279.

171. Kim YG, Lee CK, Nah SS, Mun SH, Yoo B, Moon
HB. Human $\mathrm{CD} 4{ }^{+} \mathrm{CD} 25^{+}$regulatory T cells inhibit the differentiation of osteoclasts from peripheral blood mononuclear cells. Biochem Biophys Res Commun. 2007;357(4):1046-1052.

172.Zaiss MM, et al. Treg cells suppress osteoclast formation: a new link between the immune system and bone. Arthritis Rheum. 2007;56(12):4104-4112.

173. Liu Y, et al. Mesenchymal stem cell-based tissue regeneration is governed by recipient $\mathrm{T}$ lymphocytes via IFN- $\gamma$ and TNF- $\alpha$. Nat Med. 2011;17(12):1594-1601.

174. Liu Y, Yang R, Shi S. Systemic infusion of mesenchymal stem cells improves cell-based bone regeneration via upregulation of regulatory $\mathrm{T}$ cells. Tissue Eng Part A. 2015;21(3-4):498-509. 